\title{
The Use of Water Soluble Tertiary Amine Reagent for Solubilization and Metal Determination in Fish Muscle Tissue
}

\author{
Maria H. A. Melo ${ }^{*, a}$, Antonio C. S. Costa ${ }^{a}$, Joaquim A. Nóbrega ${ }^{b}$ and Sérgio L. C. Ferreira \\ ${ }^{a}$ Instituto de Química, Universidade Federal da Bahia, 40170-290 Salvador - BA, Brazil \\ ${ }^{b}$ Departamento de Química, Universidade Federal de São Carlos, 13080-900 São Carlos - SP, Brazil
}

\begin{abstract}
A extração de metais com aminas terciárias solúveis (reagente CFA-C) assistida por ultra-som e em presença de peróxido de hidrogênio foi usada para solubilização de metais em amostras de peixe. Duas espécies de peixes de águas naturais (Pseudoplatystoma coruscans e Salminus brasiliensis), diferindo basicamente no teor de lipídio, foram utilizadas. A etapa de otimização foi desenvolvida com o auxílio de planejamento fatorial. O procedimento proposto permitiu a extração quantitativa de $\mathrm{Ca}, \mathrm{Cu}, \mathrm{Fe}, \mathrm{Mg}$ e $\mathrm{Zn}$. No processo de validação da metodologia analítica, a exatidão foi comparada com procedimento de digestão ácida em bombas Parr e usando um material certificado de referência (Fish homogenate, MA-A-2, IAEA). Todos os resultados obtidos foram concordantes ao nível de $95 \%$ de confiança, em teste $\mathrm{t}$-pareado.
\end{abstract}

The ultrasound assisted metal extraction with water soluble tertiary amines (CFA-C reagent) in presence of hydrogen peroxide was used for improving metal solubilization in fish samples. Two species of freshwater fish (Pseudoplatystoma coruscans e Salminus brasiliensis), differing basically in lipid content were used. The optimization step was carried out using a factorial experimental design. The proposed procedure allowed the quantitative extraction of $\mathrm{Ca}, \mathrm{Cu}, \mathrm{Fe}, \mathrm{Mg}$, and $\mathrm{Zn}$. In the validation process accuracy was evaluated by comparison with the total acid digestion of the sample in Parr a digestor and using a certified reference material (Fish homogenate, MA-A-2, IAEA). All results were in agreement at a $95 \%$ confidence level according to a paired-t test.

Keywords: extraction, fish muscle tissue, metal, ultrasound, tertiary amines

\section{Introduction}

Trace metal analysis in food matrices is always an important task either from toxicological or nutritional standpoint. ${ }^{1}$ The focus of interest is the suitability of daily intake of essential elements by the general population. Taking into account that food is the main source of these elements, it is significant to monitor their concentration in several types of foodstuffs. ${ }^{2}$

The reported level of several trace elements in fish muscle tissue vary widely with differences up to several orders of magnitude. ${ }^{3,4}$ Some of these variabilities are due to natural causes like fish species, age, site, body size, and feeding habits. Other factors can also affect the observed variability, e.g. procedure of analysis. The most critical step in chemical analysis is metal solubilization prior to determination. Studies for the selection of the digestion method are regularly being published but no general

* e-mail:mhamelo@ufba.br agreement has been achieved. ${ }^{1,5,6}$ There is still need for simpler, rapid and more efficient procedures.

Ultra-sound-assisted extraction technique is considered a simple and inexpensive alternative for sample preparation. ${ }^{7}$ It was first investigated for extraction of metals with dilute acid solution in biological samples. ${ }^{8-11}$ Sonication time varied from 1 to $5 \mathrm{~min}$ for probe ultrasound equipment and from 4 to $120 \mathrm{~min}$ for bath equipment. The most commonly used reagent for ultrasound extraction was $\mathrm{HNO}_{3}$. For fish samples only one method was found, a $\mathrm{Hg}$-speciation procedure using $\mathrm{HCl}$ as extractor. ${ }^{12}$

The leaching of inorganic constituents by complex formation was also investigated. Uchida et al. ${ }^{13}$ used tetramethylammonium hydroxide (TMAH) and ethylenediaminetetracetic acid (EDTA) in sealed PTFE vessel for extraction of metals from biological samples. Inductively coupled plasma optical emission spectrometry (ICP OES) determination at the supernatant solution was acceptable for 10 elements in most of botanical and zoological reference materials, but recoveries were not 
quantitative for human hair. Poor results were obtained in almost all samples for $\mathrm{Al}$ and $\mathrm{Fe}$, with recoveries around 60-70\%. Zhou et al. ${ }^{14}$ extended this approach using a microwave-assisted system for both botanical and zoological materials. High blank values were observed. A similar chemical system was adopted for extraction in closed vessel microwave digestion oven for $30 \mathrm{~min}$. The method was applied for determining 10 elements in certified samples with good recoveries for most of them. Low recoveries for $\mathrm{Al}$ and $\mathrm{Fe}$ were again observed.

A strategy of extraction by complexation with a mixture of water-soluble tertiary amines and EDTA was reported by Nóbrega et al. ${ }^{15,16} \mathrm{~A}$ suspension of the sample was prepared by stirring for $30 \mathrm{~min}$ with a $10 \%$ (v/v) aqueous solution of the reagent and after centrifugation the supernatant was used for direct ICP OES and inductively coupled plasma mass spectrometry (ICP-MS) determination. A large number of metals was successfully determined. They also reported difficulties with $\mathrm{Al}$ and $\mathrm{Fe}$ recoveries.

In this paper sonication and complexation extraction procedures were used with the purpose of developing a simple, accurate and precise procedure for extraction of metals from fish samples employing minimum analyst effort and routine laboratory apparatus. A mixture of water soluble amines and EDTA in the presence of hydrogen peroxide was used for extraction of metals $(\mathrm{Ca}, \mathrm{Cu}, \mathrm{Fe}$, $\mathrm{Mg}$, and $\mathrm{Zn}$ ). The determination of Fe by ICP OES in the supernatant solution was used for evaluation of the extraction efficiency because $\mathrm{Fe}$ is a difficult extractable element from biological matrices.

\section{Experimental}

\section{Apparatus}

For measurements of $\mathrm{Ca}, \mathrm{Cu}, \mathrm{Fe}, \mathrm{Mg}$ and $\mathrm{Zn}$ a Research Laboratory model 3410 minitorch sequential ICP OES (Dearborn, MI, USA), controlled by an IBM PC-AT computer was used. Emission intensities were measured under conditions shown in Table 1.

A Branson Model Bransonic 3510 ultrasonic cleaner (Branson Ultrasonics Corp., Danbury, CT, USA) was used for extraction of the analytes.

A Fanem Model 205N centrifuge was used for centrifugal separation.

Samples were dried in a domestic microwave oven National (800 W).

\section{Reagents and samples}

All reagents were of analytical grade. Ultrapure water
Table 1. Operating parameters for the inductively coupled plasma optical emission spectrometer

\begin{tabular}{|c|c|}
\hline Incident output power (W) & 650 \\
\hline Reflected power $(\mathrm{W})$ & $<5$ \\
\hline Nebulizer & Concentric (Meinhard) \\
\hline Plasma gas flow rate $\left(\mathrm{L} \mathrm{min}{ }^{-1}\right)$ & 7.5 \\
\hline Auxiliary gas flow rate $\left(\mathrm{L} \min ^{-1}\right)$ & 0.81 \\
\hline Aerosol carrier gas flow $\left(\mathrm{mL} \min ^{-1}\right)$ & 0.81 \\
\hline Solution uptake rate $\left(\mathrm{mL} \min ^{-1}\right)$ & 2.5 \\
\hline Signal integration time (s) & 5 \\
\hline Integration for determination & 3 \\
\hline \multirow[t]{5}{*}{ Emission lines (nm) } & $\mathrm{Fe}$ (II) 259.931 \\
\hline & $\mathrm{Zn}$ (II) $\quad 213.856$ \\
\hline & $\mathrm{Ca}$ (II) 317.952 \\
\hline & $\operatorname{Mg}$ (II) $\quad 279.049$ \\
\hline & $\mathrm{Cu}$ (II) 224.695 \\
\hline
\end{tabular}

was obtained from an EASYpure RF (Barnstedt, Dubuque, IA, USA). Laboratory glassware was kept overnight in $10 \%$ $(\mathrm{v} / \mathrm{v})$ nitric acid solution, rinsed with deionized water before use, and dried in a dust-free environment.

$C F A-C$ reagent. Solution containing $50 \% \mathrm{v} / \mathrm{v}$ mixed amines (CFA-C, Spectrasol, Warwick, NY, USA) prepared in saturated EDTA solution.

Reference solutions for calibration were prepared from Titrisol stock solutions (Merck) in 5\% (v/v) CFA-C reagent solution.

For evaluating the efficiency of the extraction method, a certified reference material fish homogenate, MA-A-2 from the International Atomic Energy Agency (IAEA, Vienna, Austria) was used.

Two samples of fish were acquired from a local vendor (surubim pintado - Pseudoplatystoma coruscans and dourada - Salminus brasiliensis), cleaned and treated with plastic knife for removal of muscle tissue, followed by homogenization in domestic blender, plastic bag storage, and freezing.

Drying of samples. Samples were dried by microwaveassisted heating. Fifty grams (50 g) of wet sample were spread in a dish with $20 \mathrm{~cm}$ of diameter (sample film of $0.15 \mathrm{~g} \mathrm{~cm}^{-2}$ ) and heated for $5 \mathrm{~min}$ at $200 \mathrm{~W}$ of applied power, then $25 \mathrm{~min}$ at $600 \mathrm{~W}$ with periodic turnovers. Losses of volatile compounds were not observed according to a comparison with a liophilization procedure.

Parr digestion procedure. An aliquot of $0.2 \mathrm{~g}$ of dried sample was transferred to a Parr digestor and $2 \mathrm{~mL}$ of $\mathrm{HNO}_{3}$ $65 \% \mathrm{~m} / \mathrm{m}$ and $2 \mathrm{~mL}$ of deionized water were added. The digestor was heated for $16 \mathrm{~h}$ at $170{ }^{\circ} \mathrm{C}$. After cooling, the solution was diluted in a $10 \mathrm{~mL}$ volumetric flask. ${ }^{5}$

Sample extraction procedure. An aliquot of $0.2 \mathrm{~g}$ of dried sample was transferred to a $10 \mathrm{~mL}$ volumetric flask and $300 \mu \mathrm{L}$ of $\mathrm{H}_{2} \mathrm{O}_{2} 30 \% \mathrm{~m} / \mathrm{m}$ and $1 \mathrm{~mL}$ of the amines mixture were added. After resting overnight, $2 \mathrm{~mL}$ of water 
was added to the flask and the suspension was sonicated for $25 \mathrm{~min}$. The volume was completed with $\mathrm{HCl} 50 \% \mathrm{v} / \mathrm{v}$ and the resulting extract was centrifuged at $3500 \mathrm{rev} \mathrm{min}^{-1}$ for $5 \mathrm{~min}$. The supernatant was taken for determination of metals.

\section{Results and Discussion}

Experimental designs were used in order to develop the extraction system with the least number of experiments as possible. All trials were carried according to the chosen method which allows the study of several factors simultaneously. The main goal of the study was to evaluate the relative influence of various controlled factors on the overall extraction performance, establishing the most favourable conditions. If a factor was recognized as exerting no significant effect it was maintained fixed at a suitable level.

The basic procedure adopted consisted of an ultrasound assisted extraction of metals from fish samples with CFA-C reagent followed by acidification, centrifugation, and ICP OES determination in the supernatant solution.

Initially, a fractional factorial design $2^{4-1}$ was used to study the following factors: sample mass (SM), sonication time (ST), CFA-C reagent concentration (RC), and type of acid (TA). The maximum (+1) and minimum (-1) levels used were 100 and $60 \mathrm{mg}$ for SM; 10 and $3 \mathrm{~min}$ for ST; 10 and $5 \%(\mathrm{v} / \mathrm{v})$ for $\mathrm{RC} ; \mathrm{HNO}_{3}$ and $\mathrm{HCl}$ for TA . The system responses evaluated were Fe and $\mathrm{Zn}$ contents of a certificate reference material (Fish homogenate MA-A-2 / IAEA).

The results of this design (Table 2) showed that at the levels studied the variables do not affect the system for the extraction of Zn. Quantitative recoveries are obtained in all sets of conditions generated. The analysis of variance was

Table 2. Results for the extraction of iron and zinc in the fractional factorial design $2^{4-1}$

\begin{tabular}{crrrrrr}
\hline Exp. N & SM & ST & RC & TA & Fe $(\%)$ & Zn $(\%)$ \\
\hline 1 & -1 & -1 & -1 & -1 & 65 & 102 \\
2 & 1 & -1 & -1 & 1 & 69 & 95 \\
3 & -1 & 1 & -1 & 1 & 76 & 100 \\
4 & 1 & 1 & -1 & -1 & 65 & 98 \\
5 & -1 & -1 & 1 & 1 & 67 & 98 \\
6 & 1 & -1 & 1 & -1 & 64 & 108 \\
7 & -1 & 1 & 1 & -1 & 73 & 98 \\
8 & 1 & 1 & 1 & 1 & 69 & 97 \\
9 & -1 & -1 & -1 & -1 & 69 & 104 \\
10 & 1 & -1 & -1 & 1 & 65 & 93 \\
11 & -1 & 1 & -1 & 1 & 73 & 99 \\
12 & 1 & 1 & -1 & -1 & 85 & 100 \\
13 & -1 & -1 & 1 & 1 & 67 & 105 \\
14 & 1 & -1 & 1 & -1 & 64 & 100 \\
15 & -1 & 1 & 1 & -1 & 82 & 102 \\
16 & 1 & 1 & 1 & 1 & 71 & 98 \\
\hline
\end{tabular}

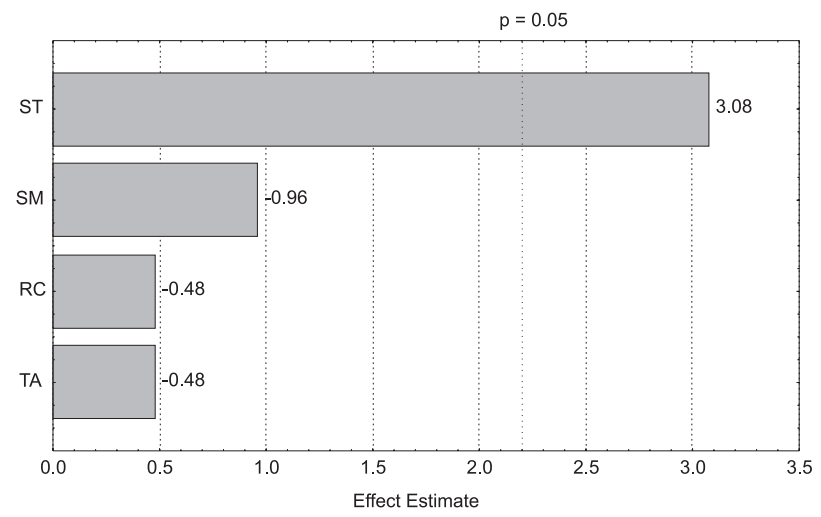

Figure 1. Pareto chart of the fractional factorial experimental design $\left(2^{4-1}\right)$ for the analysis of the variables: (SM) Sample mass; (ST) Sonication time; (RC) CFA-C reagent concentration; (TA) Type of acid.

applied to Fe results as shown in Figure 1 (Pareto chart, Statistica, Statsoft, OK, USA). No significant effect can be detected for sample mass, CFA-C reagent concentration and type of acid at these levels. The only significant variable was sonication time assuring the importance of ultra-sound assistance for this system of extraction.

A full factorial design $\left(2^{2}\right)$ was also applied for verifying the influence of sonication time (ST) considering two kinds of fish samples (KS) with different lipid contents: surubim $(5 \% \mathrm{~m} / \mathrm{m})$ and dourada $(15 \% \mathrm{~m} / \mathrm{m})$, considered level $(-1)$ and (+1), respectively. For ST the levels were $15 \min (-1)$ and $20 \mathrm{~min}(+1)$. The results obtained for the experiments are shown in Table 3. The kind of sample exerts a highly significant effect (Figure 2) which means that the lipid content has a severe influence on the performance of the system used for extraction. No interaction between these two variables was observed.

The development of any further optimization step should take into account the particular characteristics of the fish specie used in the adopted strategy. To propose a more robust procedure, the most significant variables had their levels fixed at maximum feasible values. The

Table 3. Results for the extraction of iron in the factorial design $\left(2^{2}\right)$

\begin{tabular}{cccc}
\hline Exp. $\mathrm{N}^{\mathrm{o}}$ & $\mathrm{KS}$ & $\mathrm{ST}$ & $\mathrm{Fe}(\%)$ \\
\hline 1 & 1 & 1 & 22.3 \\
2 & 1 & -1 & 22.3 \\
3 & -1 & 1 & 37.6 \\
4 & -1 & -1 & 35.5 \\
5 & 1 & 1 & 23.6 \\
6 & 1 & -1 & 20.3 \\
7 & -1 & 1 & 36.6 \\
8 & -1 & -1 & 40.0 \\
9 & 1 & 1 & 22.3 \\
10 & 1 & -1 & 18.9 \\
11 & -1 & 1 & 34.4 \\
12 & -1 & -1 & 33.3 \\
\hline
\end{tabular}




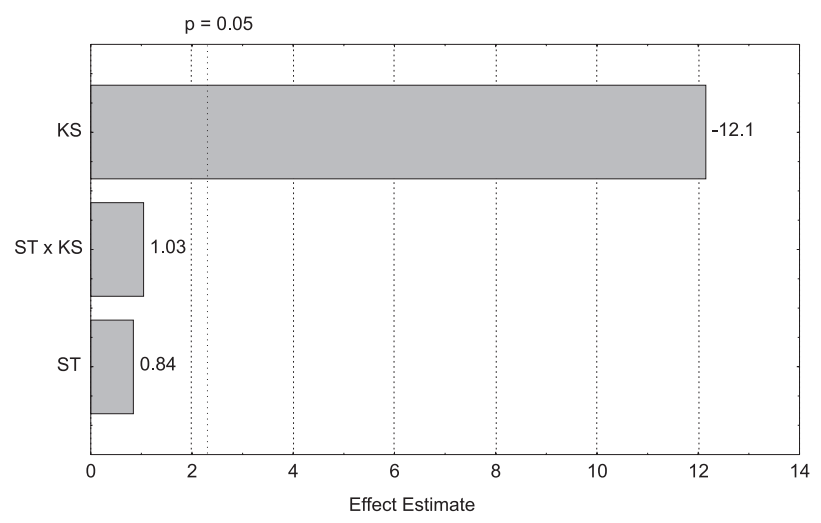

Figure 2. Pareto chart of the complete factorial experimental design $\left(2^{2}\right)$ for the analysis of the variables: (KS) Kind of sample; (ST) Sonication time.

extraction efficiency for a large group of fish samples was then assured. The procedure included a sonication time of $25 \mathrm{~min}$ and a final reagent concentration of $5 \% \mathrm{v} / \mathrm{v}$.

Iron is a difficult extractable element for both botanical and zoological samples. It is common to find low recoveries for $\mathrm{Al}$ and $\mathrm{Fe}$ by similar procedures of sample preparation. For vegetables samples, Wieteska et al. ${ }^{17}$ suggested the use of HF reagent for the purpose of solubilization of this metal. For zoological samples hydrogen peroxide was added due to its potential capability of interaction with Fe present in heme-groups of animal tissues compounds (Haber-Weiss reaction). ${ }^{18}$

The procedure was modified by addition of $300 \mu \mathrm{L}$ of hydrogen peroxide to the fish sample prior to ultra-sound assisted extraction with CFA-C reagent, overnight, in order to avoid foam formation. This modification enhanced extraction efficiency results from values of 78 to $99 \%$ for surubim and from 57 to $96 \%$ for dourada. It is clear the pronounced positive effect caused by this reagent, which is in agreement with the hypothesis of interaction between this reagent and $\mathrm{Fe}$ present in heme-groups.

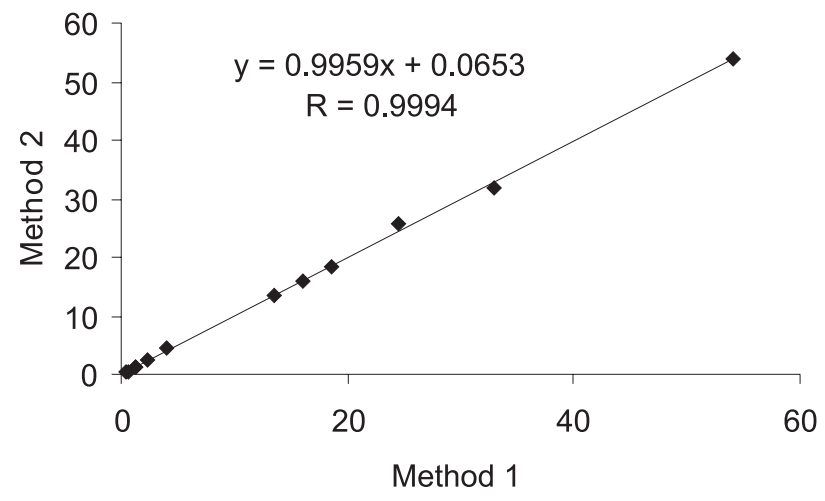

Figure 3. Regression line for results obtained by Parr digestion or certificate data (Method 1) and by CFA-C extraction (Method 2) procedures.

Good accuracy and precision were attained for Fe extraction. Relative errors of $0.7 \%$ and $1.2 \%$ were obtained and the precision, estimated as repeatability and calculated as relative standard deviation (rsd), were $3.2 \%$ and $4.9 \%$, $(\mathrm{n}=5)$ for dourada and surubim, respectively.

The proposed procedure allowed the quantitative extraction of $\mathrm{Ca}, \mathrm{Cu}, \mathrm{Fe}, \mathrm{Mg}$, and $\mathrm{Zn}$ when applied to real samples. The accuracy of the developed procedure was evaluated using a certificate reference material (Fish homogenate, MA-A2, IAEA) and by comparison of the developed procedure of digestion with the total acid digestion of the sample using a Parr digestor (Table 4, Figure 3). The regression line obtained shows the agreement between data. All results were in agreement at a 95\% confidence level according to a paired-t test.

\section{Conclusions}

Ultra-sound assisted extraction procedure with tertiary amines reagent in presence of hydrogen peroxide can be used to improve metal solubilization of fish samples.

Table 4. Analytical results for fish samples of surubim, dourada and CRM Fish homogenate (MA-A-2, IAEA) by Parr digestion procedure (1) and CFA-C extraction proposed method (2) (mean \pm SD $(n=3))$

\begin{tabular}{|c|c|c|c|c|}
\hline Element & Method & Surubim & Dourada & IAEA CRM (MA-A-2) \\
\hline $\mathrm{Fe}\left(\mu \mathrm{g} \mathrm{g}^{-1}\right)$ & $\begin{array}{l}1 \\
2\end{array}$ & $\begin{array}{c}16 \pm 2 \\
15.8 \pm 0.8\end{array}$ & $\begin{array}{l}13.5 \pm 0.7 \\
13.6 \pm 0.4\end{array}$ & $\begin{array}{c}54 \pm 1^{\mathrm{a}} \\
54 \pm 2\end{array}$ \\
\hline $\mathrm{Zn}\left(\mu \mathrm{g} \mathrm{g}^{-1}\right)$ & $\begin{array}{l}1 \\
2\end{array}$ & $\begin{array}{l}18.6 \pm 0.8 \\
18.3 \pm 0.7\end{array}$ & $\begin{array}{c}24.5 \pm 1 \\
25.9 \pm 0.8\end{array}$ & $\begin{array}{c}33 \pm 1^{\mathrm{a}} \\
31.8 \pm 0.5\end{array}$ \\
\hline $\mathrm{Ca}\left(\mathrm{mg} \mathrm{g}^{-1}\right)$ & $\begin{array}{l}1 \\
2\end{array}$ & $\begin{array}{l}0.364 \pm 0.008 \\
0.368 \pm 0.005\end{array}$ & $\begin{array}{l}0.54 \pm 0.02 \\
0.54 \pm 0.02\end{array}$ & $\overline{\mathrm{NC}}$ \\
\hline $\operatorname{Mg}\left(\mathrm{mg} \mathrm{g}^{-1}\right)$ & $\begin{array}{l}1 \\
2\end{array}$ & $\begin{array}{l}1.36 \pm 0.03 \\
1.35 \pm 0.03\end{array}$ & $\begin{array}{l}1.26 \pm 0.04 \\
1.15 \pm 0.02\end{array}$ & $\overline{\mathrm{NC}}$ \\
\hline $\mathrm{Cu}\left(\mu \mathrm{g} \mathrm{g}^{-1}\right)$ & $\begin{array}{l}1 \\
2\end{array}$ & $\begin{array}{l}2.4 \pm 0.4 \\
2.4 \pm 0.6\end{array}$ & - & $\begin{array}{c}4.0 \pm 0.1^{\mathrm{a}} \\
4.4 \pm 0.6\end{array}$ \\
\hline
\end{tabular}

${ }^{a}$ Certified; (NC) - Non certified value. 
The method is reliable and characterized by suitable accuracy and precision when applied to real samples, not only for Fe determination but also to others elements such as $\mathrm{Ca}, \mathrm{Cu}, \mathrm{Mg}$, and $\mathrm{Zn}$.

\section{References}

1. Zachariadis, G.A.; Stratis, J. A.; Kaniou, I.; Kalligas, G.; Mikrochim. Acta 1995, 119, 191.

2. Zaidi, J.H.; Qureshi, I.H.; Arif, M.; Fatima, I.; Intern. J. Environ. Anal. Chem. 1995, 60, 15.

3. Sindayigaia, E.; Van Cauvenbergh, R.; Robberecht, H.; Deelstra, H.; Sci. Total Environ. 1994, 144, 103.

4. Engman, J.; Jorhem, L.; Food Addit. Contam. 1998, 15, 884.

5. Bortoli, A.; Gerotto, M.; Marchiori, M.; Muntau, H.; Rehnert, A.; Mikrochim. Acta 1995, 119, 305.

6. Kakulu, S. E.; Osibanjo, O.; Ajayi, S. O.; J. Environ. Anal. Chem. 1987, 30, 209.

7. Oliveira, E.; J. Braz. Chem. Soc. 2003, 14, 174.

8. Minami, H.; Honjyo, T.; Atsuya, I.; Spectrochim. Acta, Part B 1996, 51, 211.

9. Mierzwa, J.; Adeloju, S.B.; Dhindsa, H.S.; Anal. Sci. 1997, 13, 189 .
10. Azouzi, H. A.; Cervera, M.L.; de la Guardia, M.; J. Anal. At. Spectrom. 1998,13, 533.

11. Lavilla, I.; Capelo, J.L.; Bendicho, C.; Fresenius. J. Anal. Chem. 1999, 363, 283.

12. Rio-Segade, S.; Bendicho, C.; J. Anal. At. Spectrom. 1998, 14, 263.

13. Uchida, T.; Isoyama, H.; Yamada, K.; Oguchi, K.; Nakgava, G.; Sugie, H.; Iida, C.; Anal. Chim. Acta 1992, 256, 277.

14. Zhou, Z.Y.; Wong, M.K.; Koh, L.L.; Wee, Y.O.; Talanta 1996, 43, 1061.

15. Nobrega, J. A.; Gelinas, Y.; Krushevska, A.; Barnes, R.M.; J. Anal. At. Spectrom. 1997, 12, 1243.

16. Nobrega, J. A.; Gelinas, Y.; Krushevska, A.; Barnes, R.M.; J. Anal. At. Spectrom. 1997, 12, 1239.

17. Wieteska, E.; Zioék, A. Drzewiñska, A.; Anal. Chim. Acta 1996, 330, 251.

18. Silver, J.; Chemistry of Iron, Blackie Academic and Professional: London, 1996.

Received: November 24, 2003

Published on the web: December 16, 2004

FAPESP helped in meeting the publication costs of this article. 